\title{
Pola Kellèghán dan Teknik Vokal Kèjhungan Representasi Ekspresi Budaya Madura dan Pengalaman Estetiknya
}

\author{
Zulkarnain Mistortoify \\ Jurusan Etnomusikologi Institut Seni Indonesia Surakarta \\ Timbul Haryono, Victor Ganap, dan G.R. Lono L. Simatupang \\ Pengkajian Seni Pertunjukan dan Seni Rupa, Universitas Gadjah Mada Yogyakarta
}

\begin{abstract}
ABSTRAK
Kèjhungan adalah gaya nyanyian Madura yang memiliki ciri-ciri kontur melodi dengan didominasi nada-nada tinggi, penuh dengan ketegangan suara (nyaring), ekspresif, dan terpola. Kèjhungan seringkali dianalogikan sebagai sebuah bentuk ekspresi "keluh-kesah" semata. Kelantangan suara, ketinggian nada, dan pengolahan melodi yang penuh melismatis mengesankan nyanyian ini seperti orang yang sedang berteriak, membentak, dan merintih-rintih. Penelitian ini dilakukan untuk mengungkap hubungan antara karakteristik kèjhungan dengan dunia pengalaman manusia pemiliknya. Oleh karenanya, aspek yang dikaji tidak hanya melihat aspek materi nyanyian itu sendiri, melainkan melihat pula perilaku menyanyikannya. Melalui analisis struktural-hermeneutik dan pendekatan etnoestetik, ditemukan bahwa kellèghãn (pola-pola kalimat lagu) menjadi karakteristik pokok dari bentuk kèjhungan dan teknik vokalnya yang bertumpu pada capaian ekspresi yang "menggebu-gebu". Ide dan konsep yang tergali dibalik itu menunjukkan adanya relasi antara kebiasaan menyanyi orang Madura dengan pengalaman sejarah sosial-budayanya. Hasil penelitian ini menunjukkan bahwa nyanyian Madura secara fenomenologis memberikan petunjuk yang sangat jelas sebagai representasi dari ekspresi budaya dan pengalaman estetik, khususnya pada sub kultur barat Madura.
\end{abstract}

Kata kunci: kellèghãn, teknik vokal, ekspresi budaya, pengalaman estetik

\begin{abstract}
Kellèghän Pattern and Kèjhungan Vocal Technique, the Representation of Madurese Cultural Expression and Aesthetic Experience. Kèjhungan is a singing style specific to Madurese. It features the patterned melodic contour dominated by high pitch vocal, expressiveness, and full of vocal intensity. Madurese kèjhungan is often misperceived only as a form of "moaning" due to its piercing sound, high pitch note, and melismatic melody. Kèjhungan gives an impression of a person shrieking and moaning at the same time. The study of kejhhungan was conducted to reveal the relationship between the singing characteristic and human experiences. Therefore, kèjhungan aspects should not only focus on the singing material itself, but it should also include a study on how people sing it. Using the structural-hermeneutic analysis and ethno aesthetic approach, the kellèghan (patterns of musical phrase) and vocal techniques that rest upon volatile expression are the basic characteristics of kejhhungan. The idea and concept behind those techniques show a connection between Madurese singing practice and the chronicle of their socio-cultural experience. Finally, this research shows that in phenomenological aspect it gives a very clear clue on the representation of the Madurese culture expression and aesthetic experience, especially the sub-culture of West Madura.
\end{abstract}

Keywords: kellèghãn, vocal techniques, culture expression, aesthetic experience

\section{Pendahuluan}

Gaya nyanyian Madura atau dikenal dengan sebutan kèjhungan, memiliki kekhasan yang mencerminkan karakteristik local genius yang kuat. Demikianlah pandangan utama yang muncul dari banyak kalangan yang telah mengenalinya. Pelaku kèjhungan (tokang kèjhung) dikenal memiliki cara

${ }^{1}$ Alamat korespondensi: Jln. Ki Hajar Dewantara 19, Kentingan, Surakarta, 57126. HP: 081329224066. Email: mistortoify@yahoo.com dan zoelmis@gmail.com 
pengekspresian yang menggebu, terkesan spontan, dan menyukai permainan nada-nada tinggi yang kemudian membentuk pola-pola melodi yang disebut kellèghãn. Karakteristik kèjhungan yang relatif berbeda dengan kultur nyanyian daerah lainnya, menyebabkan timbulnya penilaian terhadapnya. Kèjhungan seringkali dianalogikan sebagai sebuah bentuk ekspresi "keluh-kesah" semata. Kelantangan suara dengan sajian nada-nada tinggi dikesankan seperti orang yang sedang berteriak, membentak, bahkan seperti merintih-rintih atau mengeluh. Sejumlah kesan umum di atas setidaknya merupakan gambaran awal tentang ekspresi nyanyian orang Madura.

Nyanyian merupakan tindakan komunikasi yang spesifik karena berhubungan dengan perilaku menyanyi. Lomax (1976: 11) menyebut perilaku khas semacam itu sebagai gaya. Mempelajari gaya nyanyian sama halnya mempelajari teknik dan kebiasaan menyanyi, dan bukan terletak pada materi nyanyian itu sendiri. Jika demikian, kèjhungan seharusnya dilihat tidak hanya aspek bentuknya saja, melainkan harus dilihat pula dari perilaku menyanyikannya (teknik atau cara kerjanya). Jika kèjhungan diasumsikan telah dimaknai secara komunal, maka studi ini selayaknya tidak hanya mencermati wujud dan teknik nyanyiannya saja, melainkan mengungkapkan nilai-nilai yang melatarbelakanginya. Pengungkapan atas suatu gaya nyanyian ibarat sebuah "pintu masuk" untuk mengetahui "isi ruangan" (nilai-nilai) yang hanya ada dalam dunia ide, konsep, keyakinan, dan pengalaman manusianya.

Penelitian ini selain mengungkap sisi bentukstruktur kèjhungan dan cara-cara penyanyiannya, juga mengungkap hal-hal penting atas fenomena musikal kèjhungan melalui upaya penggalian konsep estetik dalam budaya musik orang Madura. Topik spesifik ini dipilih penulis karena termotivasi untuk menggalinya lebih dalam mengenai keberadaan sebuah gaya nyanyian leluhur Madura yang dulunya eksis dan menyeluruh, tetapi saat ini hanya hidup di komunitas tertentu yang masih mempertahankan artikulasi kemaduraan secara adat. Amat disayangkan bahwa perhatian terhadap aset karya estetik ini masih dipandang rendah hanya karena disebabkan pengetahuan yang terbatas dan komitmen yang lemah dari pihak yang berwenang. Pentingnya topik ini bagi kebudayaan Madura bahwa gaya nyanyian lokalnya sebetulnya dapat berbicara banyak mengenai pemahaman karakteristik ekspresi estetik masyarakat pemiliknya dan jatidiri budayanya. Kèjhungan sebagai ekspresi gaya nyanyian dapat menerangkan sejumlah pengalaman terdalam manusia, menghantarkan imajinasi atau persepsi masyarakat pemiliknya ke arah pengalaman tertentu. Sebagaimana Bruner (1986: 5-6) ungkapkan bahwa relasi ekspresi seni dan pengalaman manusia merupakan hubungan dialektis. Ketika "pengalaman menstruktur ekspresi”, maka "ekspresi juga dapat menstruktur pengalaman".

Objek material penelitian ini adalah nyanyian yang dikaitkan dengan gejala-gejala lain yang melingkupinya. Sementara, objek formalnya menggunakan dua pendekatan, yaitu pendekatan struktural-hermeneutik untuk menjelaskan struktur dan teknik nyanyiannya, serta pendekatan etno-estetika untuk mengungkap persoalan konsep-konsep lokal (idealistik dan estetik) yang mendasari kèjhungan, serta pemaknaan-pemaknaan yang muncul dari persepsi tineliti dan dalam sistim pengetahuan mereka. Berdasarkan topiknya, penelitian ini memerlukan keterlibatan peneliti dalam metode pengumpulan datanya, sebab hal itu merupakan metode kerja lapangan yang menjadi syarat mutlak untuk lebih memahami tentang perilaku dan pikiran subjek yang diteliti. Sementara, secara kombinatif penggunaan metode analisis musikologis, etnografis, dan interpretatif sangat dimungkinkan di dalam pendekatan "strukturalhermeneutik" dan pendekatan etno-estetik.

\section{Kèjbungan sebagai Nyanyian Bergaya Khas Madura}

Kata kèjhungan berasal dari kata kèjhung yang menunjuk pada arti tembang atau lagunya, sedangkan imbuhan "an" menunjuk pada arti gaya atau langgam suatu nyanyian. Pengertian di masyarakat, kèjhungan bisa bermakna sangat umum, yaitu "sebuah nyanyian" saja, atau segala hasil aktivitas orang menyanyi. Kèjhungan dapat berarti pula sebagai "nyanyian ala Madura" yang berkonotasi sebagai sebuah genre. Apabila 
kèjhungan diartikan sebagai nyanyian bergaya khas Madura, maka pengertian kèjhungan mencakup pula makna kepemilikan, yaitu nyanyian rakyat yang diwariskan secara lisan dan memiliki implikasi terhadap seperangkat nilai yang mencerminkan pengalaman, pengetahuan, cara-cara pengungkapan atau modus ekspresi tertentu. Pengertian terakhir inilah yang kemudian dipakai dalam mendudukkan kèjhungan pada topik tulisan ini.

Apabila istilah kèjhungan dikembalikan pada konteks fenomena bahasa, maka menurut perkiraan Pigeaud secara morfologi dan semantik, istilah kèjhungan memiliki kesetaraan dengan kidungan jawatimuran. Menurut Hutomo (Supriyanto, 1994: 1), pengertian "kidungan" adalah bentuk nyanyian yang digerakkan dari fenomena "pembacaan" puisi sastra Jawa yang di dalamnya telah terdapat aturan tertentu. Aturan tertentu yang dimaksud dalam puisi sastra Jawa mempunyai ciri tertentu pada jumlah baris, jumlah suku kata, dan rima akhir kalimat dalam suatu jenis kidungan tertentu.

Pengertian kidungan yang berkembang di lingkungan rakyat awam justru dipahami lebih dinamis dan bahkan disederhanakan. Kidungan menjadi identik dengan pantun yang di dalamnya memuat aturan "sampiran" dan "isi", yaitu bagian awalan dan inti. Menurut Endraswara (2005: 59), "sampiran" merupakan ancang-ancang melakukan sesuatu atau sekedar bunga-bunga yang membutuhkan penyelesaian dan jawaban untuk membentuk rangkaian isinya, sedangkan "isi" merupakan kandungan dari inti parikan yang bisa disebut pula sebagai buahnya. Setidaknya di Jawa Timur (termasuk Madura), kidungan di lingkungan rakyat merupakan puisi berbentuk pantun atau parikan yang berkembang secara dinamis (Supriyanto, 1994: 1). Pengertian ini sekaligus membedakan dengan definisi Hutomo tentang puisi kidungan di atas yang masih mempertimbangkan aturan secara ketat.

Kèjhungan, dalam aspek penggunaannya memiliki dua pengertian, yaitu kèjhungan dalam konteks sajian formal dan konteks keseharian. Kèjhungan dalam konteks sajian formal merupakan kegiatan (praktik) menyanyi yang mengacu pada "norma" struktur gending yang diiringi oleh gamelan. Kèjhungan sajian formal itu umumnya disebut sebagai “kèjhungan gending”. Artinya, format penyajian kèjhungan berorientasi pada bentuk gending. Selain itu, kèjhungan gending mengacu pada konsep "padhang-ulihan" [Jawa], yaitu sebuah gejala musikal yang muncul ketika nyanyian tersebut memiliki alur antesedent (frase tanya) dan consequent (frase jawab) pada frase-frase musikalnya.

Beberapa informan mengatakan bahwa munculnya struktur "kèjhungan gending” Madura sa-ngat dipengaruhi oleh struktur kidungan jawatimuran, karena sebelumnya kèjhungan hanyalah sebuah fenomena bersenandung diri yang tumbuh dari curahan hati seseorang yang barangkali orientasi musikalnya tidak diketahui dengan pasti. Tatkala kemudian kèjhungan menunjukkan orientasinya pada struktur gending, maka "kepastian" konvensinya mulai dapat dibaca. Dalam konteks sajian gending, kèjhungan tidak lagi lepas dari gamelan sebagai pengiringnya. Acuan dasar kèjhungan adalah struktur atau kerangka gending itu sendiri, satuan irama, serta fungsi nada (modus/pathêt [jw]) yang mengoperasikannya. Salah satu contoh penting dari penempatan kèjhungan dalam struktur gending adalah pengadopsian struktur gending Jula-Juli jawatimuran ke dalam kèjhungan. Kèjhungan bârä’ atau kèjhungan yang berkembang di wilayah sub kultur barat Madura, mengadopsi gending Jula-Juli tersebut menjadi gending Yang-Layang di Madura. Kata "layang" berarti pesan atau nasehat. "Yanglayang" merupakan sekumpulan pitutur tentang pesan moral yang disenandungkan (èkèjhungaghi) agar pesannya lebih berkesan.

Praktik kèjhungan dalam konteks keseharian (sering disebut jhung-kèjhungan) dimaknai sebagai bentuk aktivitas menyanyi yang dilakukan secara spontanitas, tidak terencana, sangat tergantung pada suasana hati, serta hanya dilakukan oleh orang-orang yang sudah memiliki apresiasi yang mendalam terhadap dunia kèjhungan. Praktik jhung-kèjhungan secara riil tanpa diiringi gamelan, tetapi bukan berarti si pelaku tidak memiliki acuan terhadap ide struktur musikal. Setidaknya, mereka tetap memiliki ancangan terhadap imajinasi padhang-ulihan sebagai fenomena paling mendasar atas perilaku musikal mereka. Bouvier (2002: 286) 
mengidentifikasi kèjhungan atau lalongèdhän bahwa ketika seseorang sudah menghiasi (memperindah) kalimat lagunya dengan cara-cara yang khas, yaitu seperti "meliuk-liukkan" melodi nyanyian secara melismatis (beberapa nada yang dimainkan dalam satu suku kata) dan memberi ornamen-ornamen tertentu, maka sesungguhnya orang itu sudah melakukan "nyanyian yang sebenarnya".

"Kèjhungan gending" juga perlu dibedakan dengan lagu-lagu rakyat yang "tidak diperindah" (meminjam pengertian Bouvier di atas) seperti lagu dolanan rakyat Madura atau istilah lokalnya kèjhung èn-maènan (permainan/dolalan [Jw], dan "main-main"/ tidak serius/ sekadarnya). Lagu rakyat Madura sebagian besar terkategori sebagai lagu dolanan (lihat pula Pawitra, 2003). Keberadaannya memang tidak dirancang untuk dibawakan dalam orientasi gending, melainkan menekankan pada pemaparan lirik dengan melodi yang lugas. Melodi nyanyiannya sederhana dan mengabaikan detail ornamennya. Kebanyakan lagu rakyat dimainkan tanpa iringan gamelan, tetapi nampak menggairahkan apabila diiringi orkes tabuhan ritmis.

\section{Mencari Inti Kèjbungan}

Apa yang paling penting dari kèjhungan Madura? Hal mendasar yang perlu diketahui terlebih dahulu adalah ketika seseorang melakukan kèjhungan. Penulis pada akhirnya menemukan jawaban tentang sesuatu yang sangat diperhatikan oleh pemilik kèjhungan ketika mereka berbicara tentang aspek material kèjhungan dan teknik (cara) menyanyikan. Dalam artikel ini ini, penulis perlu mempersingkat penjelasan atas temuan tentang objek material tekstual (musikologis) ini dengan sebuah cara pemaparan secara taksonomis. Taksonomi sebagai sebuah cara untuk melihat posisi domain utama diantara berbagai domain yang melingkupinya. Apabila melihat kembali pikiran Lomax di atas, sesungguhnya implikasi atas temuan ini akan berlanjut hingga pada pertanyaan ideal, yaitu mengapa material (pola kellèghãn) dalam kèjhungan beserta tekniknya itu dianggap penting?

Taksonomi digunakan untuk menjelaskan tingkatan domain yang ada serta hubungan antar domain dari yang umum menuju domain terpenting atau inti. Skala taksonomi dibuat dalam lingkup kecil yang dibatasi pada kisaran bentuk-bentuk nyanyian lokal berbasis kèjhungan bârä sebagai sebuah genre nyanyian yang eksis di sub kultur Madura Barat. Sementara, fenomena nyanyian yang berada di luar skala pengertian tersebut dianggap bukan sasaran yang akan dijabarkan dalam domain ini. Contohnya, gaya-gaya nyanyian yang hidup di Madura Barat tetapi di luar pengertian kèjhungan bãrä, seperti: gaya nyanyian berbasis budaya Arab, budaya diatonis musik Barat/musik pop; kèjhungan tèmor, genre nyanyian sub kultur Madura Timur; serta budaya kidungan jawatimuran (terutama gaya Surabaya). Ketiga budaya nyanyian ini realitasnya hidup berdampingan dengan nyanyian lokal yang berbasis kèjhungan bãrã.

Penulis menemukan beberapa domain yang dapat menuntun ke arah domain inti. Ada empat domain yang harus dilalui untuk sampai pada domain inti, yaitu pola kellèghãn. Pembacaannya bahwa "domain inti adalah bagian dari domain yang lebih besar", demikian seterusnya hingga domain yang paling umum atau besar. Batasan domain yang paling besar adalah bentuk-bentuk nyanyian lokal yang berbasis pada kèjhungan bãrä (area kewilayahan sub kultur Madura Barat). Gambar 1 adalah bentuk ilustrasi dari pemikiran di atas.

Domain pertama, meliputi berbagai bentuk "kèjhungan” dalam skala nyanyian lokal Madura Barat. Sebagaimana telah dijelaskan sebelumnya, kèjhungan gending merupakan kèjhungan yang mengacu dan dipraktikkan dalam gendinggending Madura. Jhung-kèjhungan adalah bentuk

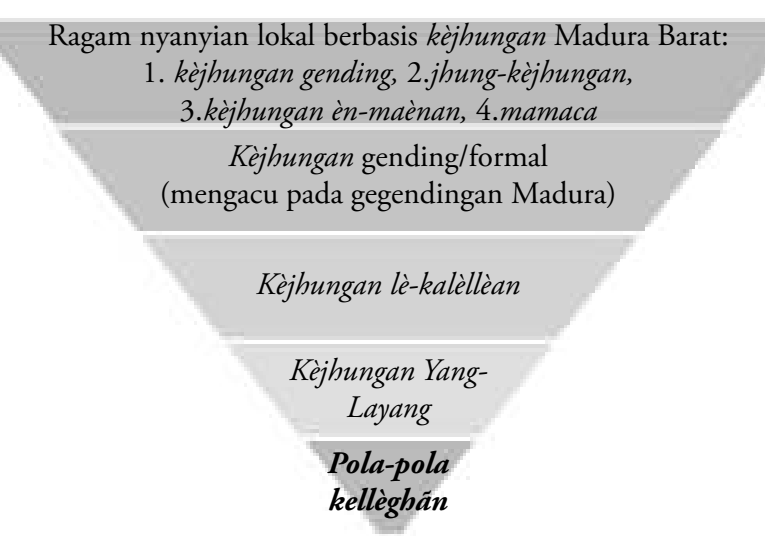

Gambar 1. Taksonomi menuju inti kèjhungan 
aktivitas bersenandung diri yang dilakukan secara spontanitas, tidak terencana, tergantung pada suasana hati sang pelaku kapan dan di manapun ia meng-inginkannya. Kèjhung èn-maènan adalah praktik nyanyian dari lagu-lagu dolanan rakyat Madura yang umumnya dibawakan tanpa teknik dan gaya yang khas ("tidak diperindah" sebagaimana dalam kèjhungan gending). Mamaca (seni resitasi), dalam hal ini digolongkan dalam domain kèjhungan karena alasan musikologis. Artinya, orientasi musikalnya memiliki kesamaan dengan karakteristik vokalisasi kèjhungan, seperti memiliki atmosfir kontur melodi nyanyian yang banyak didominasi nada-nada tinggi, terdapat penggunaan gejala "kellèghân", serta teknik vokal yang pada bagian tertentu memiliki kesamaan. Perbedaannya terletak pada bentuk dan struktur nyanyian, konsep penyanyian, serta cengkok dasar mamaca berada di luar "norma" cengkok kèjhungan pada umumnya.

Domain kedua, mengarah pada kèjhungan yang mengacu dan dipraktikkan dalam gendinggending Madura. Kèjhungan gending berada dalam kendali tema balungan gending, terutama mengacu pada nada seleh (kadens) di setiap tabuhan Kenong (frase musikal). Di Madura Barat, ada beberapa gending pokok yang sering dimainkan antara lain: gending Yang-Layang (Jula-Juli [Jw]), Cokro (Cokronegoro [Jw]), Blandaran, Celeng Mogok, Sabrang atau Potongan (Sabrang Wetan [Jw]), Samira, dan sebagainya. Kèjhungan gending merupakan "pintu masuk" menuju domaindomain yang lebih spesifik.

Domain tiga, mengarah pada bentuk kontur melodi kèjhungan yang memiliki sifat-sifat yang disebut lè-kalèllèan, yaitu ekspresi pergerakan melodi nyanyian yang seperti mengayun, menyeret, biasanya begitu menonjol dalam permainan nadanada tinggi dan ketegangan suara yang santa' (nyaring/bertenaga atau powerfull). Sifat lè-kalèllèan ini umumnya ditemukan dalam jenis kèjhungan gending, walaupun tidak semua kèjhungan gending selalu demikian. Sifat lè-kalèllèan dinilai paling representatif terdapat pada kèjhungan (gending) Yang-Layang.

Domain empat, mengarah pada kèjhungan gending Yang-Layang yang memiliki pola kontur melodi spesifik dan konsisten. Tipikal kontur melodinya memiliki pola dasar dari permainan nadanada tinggi yang membentuk pola kellèghân lalu secara tiba-tiba konturnya menurun tajam pada permainan level nada-nada sedang ke nada-nada rendah hingga akhir frase (kalimat lagu). Kèjhungan Yang-Layang yang kemudian diformalkan menjadi sebuah gending, merupakan satu-satu kèjhungan gending dan kèjhungan jenis lè-kalèllèan yang paling mengakomodasi struktur nyanyian yang syarat dengan pola-pola kellèghãn.

Domain lima, mengarah pada inti kèjhungan yaitu kellèghan. Kellèg adalah kata dasar dari kellèghãn, dan mengarah pada pengertian intonasi atau nada-nada tinggi. Sementara, kellèghân sendiri lebih dimaknai sebagai pola permainan vokal nadanada tinggi yang diolah secara ornamentik dan melismatik. Umumnya, kellèghan membentuk pola-pola yang kemudian menjadi bagian dari awal setiap kalimat lagu (frase musikal). Kata "kellèg" secara etimologi memiliki kedekatan bentuk kata dengan kata "ngelik" dalam istilah karawitan Jawa, serta kedekatan semantik dengan makna ngelik itu sendiri yang berarti suara meninggi. Perbedaannya, menurut Sumarsam (2003: 350), ngelik merupakan bagian kedua dari suatu gending yang biasanya dimulai dengan lagu berwilayah nada-nada tinggi. Sementara dalam kèjhungan, kellèg umumnya berada di bagian awal setiap kalimat lagu.

Hasil riset menunjukkan bahwa kèjhungan yang syarat dengan sifat lè-kalèllèan dan pola kellèghãn tersebut sangat menonjol penggunaannya pada kèjhungan gending Yang-Layang. Akibat dari dominasinya itu, gending Yang-Layang dianggap sebagai "pusat" atas ciri gaya nyanyian Madura dan sekaligus dinilai istimewa. Gending ini dijadikan sebagai "wadah" untuk mengukur atau menguji kualitas kèjhungan seseorang. Tidak mengherankan jika akhirnya Yang-Layang menjadi gending yang wajib "dilakukan" oleh seorang tokang kèjhung (juru kidung), dan Yang-Layang menjadi gending yang paling sering dimainkan dan diperdengarkan. Gending yang sarat dengan cengkok khas ini akan selalu terdengar dalam setiap pementasan kesenian rakyat Madura yang berbasis tabuhan gamelan, khususnya dalam kesenian Sandur (seni pertunjukan teater rakyat Madura). Sebagaimana diakui oleh Mudrick 
(seniman), Sumbri, Muhammad, Ghaib (dari kalangan blatèr pecinta kèjhungan), serta Abdurrachman dan Adrian Pawitra (dari kalangan pemerhati kèjhungan), bahwa performa paling mendasar dari penggambaran musikal kèjhungan adalah kellèghãn itu sendiri.

\section{Pola Kellèghán di dalam Bentuk dan Struktur Kèjhungan}

Instrumen analisis untuk mengkaji suatu gaya nyanyian umumnya menggunakan instrumen analisis yang hampir sama, yaitu berkisar mengenai sistim nada, metrik ritem, bentuk dan struktur nyanyian, frase lagu, ornamen nyanyian, timbre, ambitus, artikulasi, ekspresi, suasana nyanyian, lirik dan maknanya, serta konteks yang melatarbelakangi (gaya) nyanyian tersebut. Sebagaimana Zanten (1989), penulis pun melihat kèjhungan dari persoalan bentuk dan struktur nyanyian, kontur melodi nyanyian, ornamentasi, dan sebagainya. Aspek teknik dilihat dari cara-cara pelaku memproduksi nyanyiannya dengan capaian kriteria tertentu. Aspek karakterisasi berkaitan dengan konsep emik yang membentuk karakter khas nyanyian.

Kèjhungan jenis lè-kalèllèan, jauh lebih memperhatikan peran pola-pola ornamentik melodi nyanyian dari pada keberadaan liriknya itu sendiri. Hal ini dapat terjadi karena tuntutan atas aspek melodik yang dominan, sehingga keindahan lagunya mengalahkan atau mengesampingkan aspek (pesan) liriknya. Terbukti bahwa keragaman liriklirik kèjhungan sampai saat ini boleh dikatakan tidak berkembang. Perhatian orang justru lebih tersita atau terpesona terhadap penggunaan ornamen isen-isen (kata-kata hias) daripada lirik pokoknya. Isen-isen menjadi terasa menonjol ketika dilapisi oleh ekspresi melodik yang penuh ornamen melismatik dalam permainan kellèghãn (Mistortoifi, 2010: 7). Sekilas kèjhungan merupakan gaya nyany-

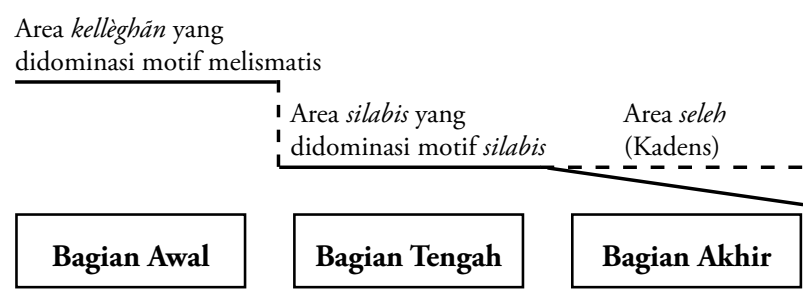

Gambar 2. Kontur melodi dasar kèjhungan dalam setiap frase (kalimat lagu) ian yang penuh ornamentik dan ekspresif. Dalam pandangan Silverberg (2010: iii, 41), sesungguhnya ornamen itu ditampilkan sebagai sebuah entri (jalan masuk) ke dalam dunia subjektivitas. Oleh karenanya, sudah seharusnya proses ornamentasi akan sangat membantu ekspresi dan sentimen si penyanyi itu sendiri, dan bukan sebaliknya.

Gambar 2 adalah gambaran mengenai pola kellèghân yang berada dalam bentuk dan struktur kèjhungan (gending) Yang-Layang. Konsep dasar dari bentuk kontur melodi kèjhungan dalam setiap frasenya bersifat descending (kontur menurun).

Frase atau kalimat lagu pada bagian awal diisi oleh tatanan nada-nada tinggi yang diolah dengan motif-motif melismatis dan membentuk pola-pola kellèghãn. Bagian awal frase ini merupakan area kellèghãn yang penting. Kontur melodi sebelum menuju ke bagian tengah memperlihatkan bentuk kontur yang menurun secara ekstrim, bahkan menyerupai "patahan". "Garis putus-putus" itu menunjukkan kontur terjal yang umumnya berjarak sekitar satu oktaf. Kesannya seperti "lompatan" dari nada tinggi langsung terjun ke nada rendah, sehingga secara faktual seringkali lompatan nada tersebut terkesan seperti suara teriakan atau bentakan.

Bagian tengah kalimat lagu umumnya menampilkan motif-motif silabis (satu nada untuk satu suku kata), namun bagian ini tidak berarti terbebas dari munculnya motif-motif melismatis. Sebab, di bagian ini dapat dikatakan sebagai area yang relatif terbuka, dalam arti tidak menutup kemungkinan adanya kontur melodi silabis yang naik dan turun, motif melismatis yang pendek, atau kontur melodi yang mendatar. Bagian akhir frase/kalimat lagu dapat disebut bagian penutup atau "ekor", mengingat arah konturnya yang mengisyaratkan sebuah akhir dari suatu kalimat. Ujungnya berupa nada seleh (kadens) yang umumnya tidak lagi menunjukkan pergerakan nada yang berarti, melainkan dibawakan secara mendatar dalam tataran nada rendah.

Contoh kongkrit dari pola kellèghãn yang muncul dalam setiap frase (kalimat lagu) dapat diamati dari kèjhungan binè ("wanita”) yang diperankan pria dewasa dan kèjhungan lakè (pria) berikut ini: 


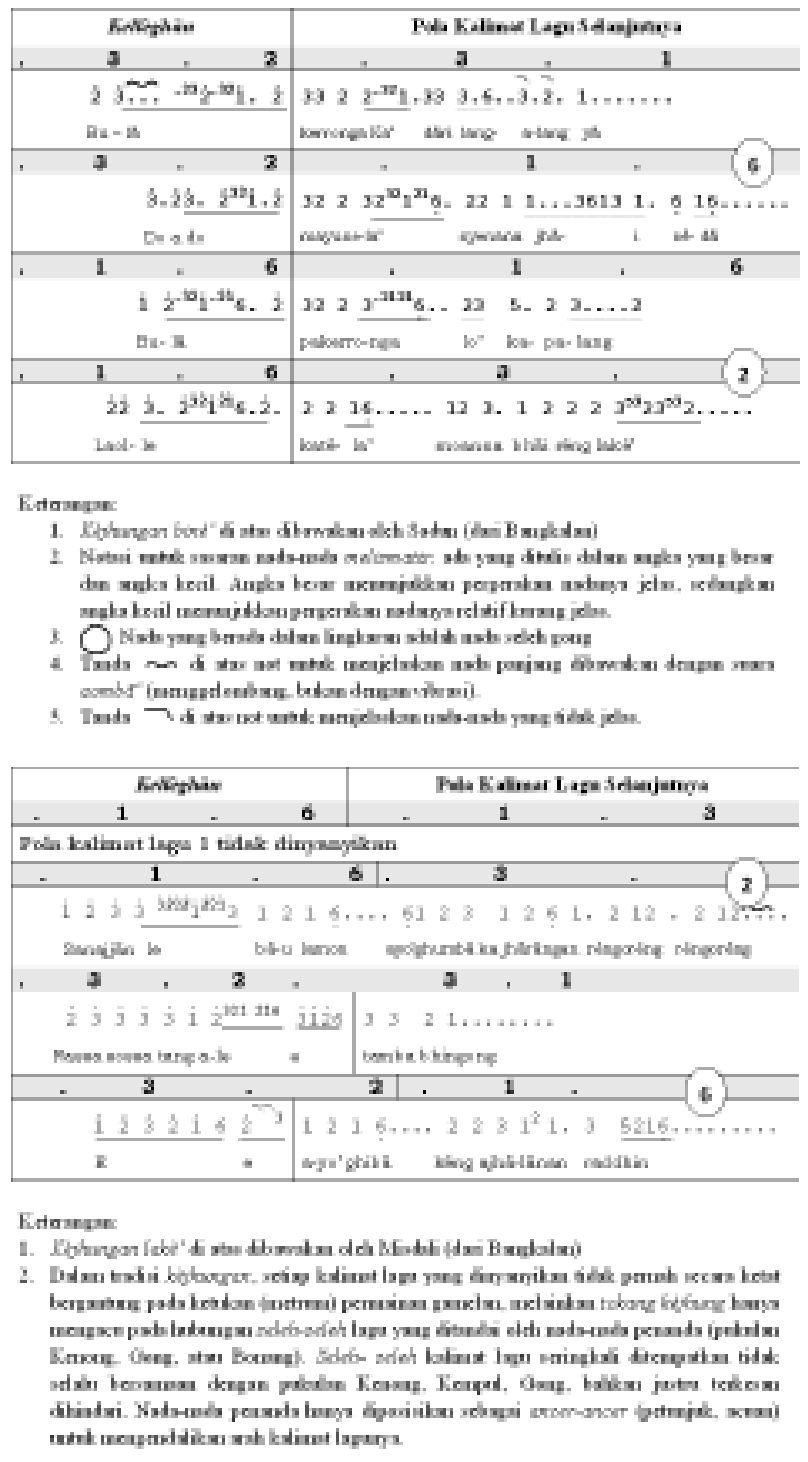

Setiap kalimat lagu kèjhungan dalam satu periode (2 gong-an) menunjukkan alur kontur yang hampir sama pada setiap perulangannya. Keragamannya terletak pada setiap individu yang menginterpretasi kalimat lagu kèjhungan YangLayang ini. Di sinilah faktor karakteristik individu berperan penting dalam memunculkan keragaman. Meskipun demikian, di satu sisi keragaman terjadi pada setiap pelaku kèjhungan, tetapi di sisi yang lain mereka umumnya enggan mengembangkan pola kalimat lagu kèjhungan lebih lanjut. Mereka cenderung "mempertahankan" pola kèjhungan dari frase-frase (kalimat lagu) yang telah dibuatnya, walaupun hal itu harus dibawakan berkali-kali dalam kurun waktu yang lama. Lirik-lirik lagu (parikan/ pantun) yang digunakan boleh saja terus berganti, tetapi pola kalimat lagunya tetap dipertahankan oleh setiap individu sebagai bagian dari jatidirinya.
Dalam hal membaca "keindahan" cengkok kèjhungan, sebuah kellèghãn dapat dinilai berbeda kriterianya antara kellèghän binè (wanita) dan lakè (pria). Karakteristik kellèghän binèlebih disarankan mampu mengolah melodi yang memperlihatkan liggu' atau ènggo' yang lebih banyak dan jelas nadanya. Liggu'l ènggo' dapat disepadankan dengan pengertian cengkok dalam konteks teknik nyanyian Jawa yang mencakup subtil gregel, luk, dan wiled. Sementara, kellèghân lakë lebih disarankan pada capaian kemantapan ketegangan suara dan greget yang lebih ditampakkan secara fisik. Oleh karenanya, greget yang menghentak-hentak pada kèjhungan lakè seringkali memperlihatkan olah nada yang tidak banyak liggu', gerakan nadanya lebih banyak menggayut (membentuk seperti luk atau glissendo dalam musik Barat) yang ekstrim sehingga rawan terhadap ketidakjelasan nadanya (pitch).

Pola dan ketinggian nada kellèghãn, kontur descending yang curam (menyerupai patahan), pitch nada yang cenderung tidak tetap (tidak stabil), bahkan ada pula gejala suara aomba (menggelombang) yang muncul pada bagian tertentu, merupakan representasi dari kontur melodi utama dari tradisi kèjhungan. Kontur utama ini mendasari terabadikannya kèjhungan YangLayang dalam sebuah gending. Dẩi (wawancara, 19 Agustus 2012) memberi kiasan penting, "kèjhungan Yang-Layang merupakan tulang punggung dari semua kèjhungan dan gending kèjhungan yang ada”. Sementara itu, gending-gending lain di luar YangLayang, kontur utama (kellèghãn) tersebut tidak dapat dilakukan secara leluasa atau tidak selalu muncul dalam keadaan utuh dalam satu frase.

Para tokang kèjhung, dalam hal ketegangan suara, membutuhkan tenaga suara yang powerfull agar mendapatkan kualitas suara yang tennyeng (tegang/kuat/mantap). Kellèghân walaupun dianggap paling sulit, memeras tenaga, dan menuntut rasa percaya diri saat dinyanyikan, namun bagi pelaku kèjhungan, hal itu adalah bagian terpenting dari kèjhungan yang harus dikuasai. Mereka menganggap bahwa kellèghãn ibarat "moanna kèjhung" ("wajah" atau bagian paling kelihatan dari praktik nyanyian Madura). Darinya, orang dapat menilai terhadap kemampuan 
seseorang melakukan kèjhungan. Masyarakat tineliti memiliki pandangan bahwa semakin tinggi nada yang dicapai (nyenthèg) yang dimainkan dalam kellèghãn, maka semakin ideal kèjhungan-nya. Para tokang kèjhung yang mengolah kellèghãn hingga mencapai nada lu (3) tinggi dari laras slendro, maka ia dikatakan telah mencapai nada yang nyenthèg (puncak). Meskipun demikian, hal yang harus dicermati adalah apakah nada tertinggi itu dicapainya dengan suara mantap (tennyeng), dan tidak dicapai dengan cara ngoyo (memaksakan diri).

Hal yang dapat digambarkan terhadap area nada-nada tinggi kellèghãn jika diukur dalam skala Hertz, maka kisarannya berada dalam 1.800 hingga 2.600 Hertz atau berada dalam kategori frekuensi menengah-tinggi (Mid-Hi atau antara $1.000 \mathrm{~Hz}$ - $6.000 \mathrm{~Hz}$ ). Hasil pengukuran nada terendah dan tertinggi para tokang kèjhung saat melakukan kèjhungan Yang-Layang apabila diterjemahkan dalam posisi nada diatonis, maka dihasilkan seperti pada Tabel 1.

Dalam dunia musik vokal klasik Barat, suara dengan batas ambitus nada E3 hingga F5 dikenal dengan istilah countertenor atau contratenor altus (Arnold, 1983: 484). Jika dibandingkan interval contratenor tersebut, maka interval nada para tokang kèjhung berkisar A3 hingga G5. Artinya, jangkauan suara tokang kèjhung berada dalam wilayah yang ideal untuk jenis suara contratenor. Kèjhungan yang dinyanyikan oleh para laki-laki dewasa terbukti telah melampaui wilayah suara laki-laki normalnya (tertinggi nada $\geq$ C5 atau bersuara tenor). Tidak mengherankan jika nada tertinggi Sadun (C5+) itu kemudian oleh beberapa pengamat kèjhungan masih dianggap kurang nyenthèg (tinggi). Berbeda halnya dengan jangkauan suara Misdali, Tabi'i, Matingwar, Marsaid, yang dinilai memiliki suara ideal (nyenthèg) dengan capaian nada tertinggi D\#5 hingga G5.

Praktik-praktik bernyanyi semacam kèjhungan umumnya menghasilkan suara yang memberi efek gema (resonansi) di kepala sang penyanyinya. Dalam dunia pedagogi vokal, jangkauan suara kèjhungan dapat diidentifikasi dalam register suara tertinggi (register suara kepala), atau juga disebut head voice. Clippinger ( 2006: 9-10) menggambarkan bahwa head voice merupakan suara yang tergolong unik, penuh kebebasan, luwes, imajinatif, dan penuh pesona. Namun untuk dapat melakukan penyuaraan head voice yang optimal, dibutuhkan kekuatan suara yang penuh dan intensitas emosional yang memadai. Kèjhungan, dalam gambaran yang ideal, juga menunjukkan kebutuhan atau tuntutan seperti

\begin{tabular}{|c|c|c|c|}
\hline No & Nama & Karakter Peran Suara & $\begin{array}{c}\text { Jangkauan Nada } \\
\text { Terendah - Tertinggi }\end{array}$ \\
\hline & Sadun & Binè' ("perempuan”) & $\mathrm{F} 4[+]--\mathrm{C} 5[+]$ \\
\hline & Matingwar & Binè’ (“perempuan”) & $\mathrm{A} 3[+]--\mathbf{F} 5$ \\
\hline & Marsaid & Binè’ (“perempuan”) & $A^{\#} 3[-]---\mathbf{F} 5[-]$ \\
\hline & Suja'i/Marju & Binè’ (“perempuan”) & A3[+] --- F5 (falsetto) \\
\hline & Grup "Bintang Remaja” & Binè’ (“perempuan”) & A3 --- F5[-] \\
\hline & Grup “Panca Rukun” & Binè’ (“perempuan”) & B3 --- G5[-] \\
\hline & Matsiru & Lakè (laki-laki) & $\mathrm{G}^{\#} 4[-]---\mathrm{C} 5$ \\
\hline & Misdali & Lakè' (laki-laki) & G3 --- $\mathbf{D}^{\#} 5$ \\
\hline & Tabi'i & Lakè (laki-laki) & A3 --- F5[-] \\
\hline 10. & Grup "Panca Rukun” & Lakè (laki-laki) & B3 --- $65[-]$ \\
\hline
\end{tabular}

Tabel 1. Jangkauan nada tokang kèjhung pada kasus kèjhungan Yang-Layang Keterangan: Nada yang dicetak tebal adalah nada nyenthèg (nada tertinggi yang dianggap ideal). 
yang digambarkan Clippinger tersebut. Tuntutan tersebut menjadi nampak jelas di dalam teknikteknik vokalisasi kèjhungan dan konsep-konsep yang ideal untuk melahirkan karakteristik nyanyian ala Madura tersebut.

\section{Teknik Vokal Kèjbungan}

Kèjhungan esensinya adalah hasil kebiasaan menyanyi orang Madura yang kemudian sangat penting untuk diketahui konsep dan praktik teknik menyanyikannya. Menurut Lomax (1976: 20), ada sejumlah aspek musikal pembentuk suatu gaya nyanyian, yaitu aspek melodi, ritem, ornamentasi, tingkat ketegangan, energi (power, stressing), kapasitas artikulasi, serta hubungan nyanyian dengan organisasi orkestrasi musiknya.

Masyarakat tineliti (pelaku dan pengamat kèjhungan) mengacu pada dua aspek pokok yang berkaitan dengan teknik vokal kèjhungan, yaitu aspek keindahan lagu dan aspek kemantapan greget melakukan kèjhungan. Aspek keindahan lagu bertumpu pada penguasaan vokabuler dan daya interpretasi atas perannya (berkarakter kèjhungan lakè atau kèjhungan binè). Sementara, aspek pencapaian kemantapan greget ngèjhung bertumpu pada banyak hal, seperti bertumpu pada kualitas nyendhäl atau gejala menyanyi yang terkesan menghentakhentak; berkaitan dengan ekspresi emosional yang ditampakkan secara fisik saat menyanyi (geregetan); tennyeng (ketegangan suara), nyenthèg (capaian nada tertinggi), dan santa' (nyaring).

Teknik vokal kèjhungan Madura sebetulnya tidak membedakan antara teknik kèjhungan lakè dan binë, sebab parameter terhadap cara-cara yang digunakan bertujuan untuk mencapai target yang sama, yaitu kemantapan "suara lepas" (tidak ditahan), ketegangan suara yang optimal (powerfull) khususnya pada permainan nada-nada tinggi, serta kemantapan greget melalui pengelolaan ekspresi yang optimal. Meskipun demikian, diantara kedua karakter gender itu tetap saja ada batas "fitrah" yang membedakannya, yaitu karakteristik dasar perempuan yang tetap menyiratkan sifat-sifat kefeminimannya, dan laki-laki dengan sifat maskulinitasnya.

Mudrick (wawancara, 10 Oktober 2010) menegaskan bahwa secara umum pencapaian keman- tapan suara yang ideal bagi tokang kèjhung, selain dituntut bersuara tinggi dan bertenaga, juga harus memiliki karakter suara yang lepas dan lantang (bahkan cenderung berteriak), barulah kèjhungan itu dikatakan mantap dari segi kualitas suara. Namun, hal itu belum bisa dikatakan sempurna atau memiliki "nyawa" jika tidak ada unsur penjiwaan/ emosi yang mana di Madura dikenal dengan istilah ghregghedhãn atau geregetan. Ghregghedhãn, barangkali juga setara dengan istilah lainnya yaitu ngaret $[\mathrm{Mdr}]$. Keduanya bermakna geram, gemas, perasaan jengkel, tidak sabar, bernafsu, keinginan memuncak yang tertahan. Ghregghedhän dan ngaret dua kosakata yang paling sering diketengahkan ketika menilai kualitas emosi suatu kèjhungan. Kedua istilah itu sedikit berbeda arti dan maknanya dengan istilah greget/grêgêt [Jw], yang bermakna daya hidup, gejolak, dinamika, dan sebagainya. Sementara, ghregghedhän/ngaret merupakan emosi personal yang lebih fisikal (nampak). Tekanan yang meletup-letup (nyendhãl [Mdr]) dan dinamika ketegangan suara merupakan efek dari pengelolaan ekspresi yang menggebu, penjiwaan terhadap sesuatu yang dibayangkannya. Meskipun demikian, antara ghregghedhãn dengan greget pada pembicaraan yang umum akan dianggap sama, sebab memiliki basis makna yang sama, yaitu daya emosi.

Konsep-konsep ideal tentang kualitas kèjhungan dan teknik vokal kèjhungan yang ditemukan penulis dalam penelitian ini, yaitu antara lain:

\section{Teknik nyendhãl (menghentak)}

Teknik pengartikulasian dengan memberikan tekanan pada kata-kata (lirik lagu) dengan cara dihentak-hentakkan atau digemas-gemaskan. Turi (wawancara 10 Maret 2010) me-ngatakan bahwa pada teknik ini menekankan agar ekspresi yang ditampakkan dalam gerakan melodi itu seharusnya bertenaga dan memberi daya gedor yang signifikan. Dalam posisi seperti itu, sulit kiranya seseorang dapat memperta-hankan kejelasan lafal (artikulasi) kata-katanya. Sebab, emosi ghregghedhänngaret yang menggebu-gebu itu membawa konsekuensi terhadap kontrol pitch pelaku kèjhungan yang tidak stabil, atau kurang tepat laras/titinada. Penggunaan teknik nyendhãl ini dipandang mampu meng-akomodasi emosi 
ghregghedhän-ngaret dalam kèjhungan. Bagi tokang kèjhung yang mampu menampakkan emosi semacam itu dalam kèjhungan-nya akan jauh lebih dihargai dan mendapat tempat istimewa, daripada kèjhungan yang kurang memiliki emosi ghregghedhän-ngaret, sekalipun pitch nadanya tergolong "tepat" (tidak rosak [Mdr]; tidak blero $[\mathrm{Jw}])$.

2. Teknik nyèrèt (menyeret)

Teknik ini berlawanan sifatnya dengan teknik nyendhâl, karena teknik ini bertumpu pada satu suku kata tertentu untuk kemudian dikembangkan ("diseret") secara melodis hingga membentuk sebuah gejala melismatik (aliggu' [meliuk] atau aonjan [mengayun]). Dengan teknik ini, efek yang dicapai adalah pergerakan melodi nyanyian yang terkesan meliuk dan mengayun. Teknik nyèrèt banyak terpaparkan dalam praktik-praktik kellèghãn yang penuh dengan olah ornamen melodi yang melismatis dan didukung oleh penggunaan isen-isen atau kata-kata hias. Seperti banyak diakui para tokang kèjhung, teknik nyèrèt seringkali lebih dipahami sebagai kemampuan daya hayat individu. Sebagaimana dijelaskan di awal, kèjhungan memiliki dua sifat dasar yang seakan kontradiktif dalam satu kesatuan karakter penyanyian, yaitu sifat garang dan sedih. Jika dalam teknik nyendhãl mengakomodasi karakter lantang/nyaring, menghentak, dan menggebu, sedangkan dalam teknik nyèrèt mengakomodasi kebutuhan ekspresi yang bernuansa rassa mellas atau rintihan/kepiluan.

3. Teknik ajjhen (mendorong/menekan, ngêddhên [Jw])

Teknik ini merupakan praktik head voice yang menimbulkan efek resonansi kuat pada diri pelakunya, bahkan efek itu memberi daya rambat suara yang terdengar hingga jauh. Teknik ajjhen digunakan untuk mencapai tingkat ketegangan suara kèjhungan yang optimal, yaitu nyenthèg (nada yang melengking), tennyeng (kemantapan terhadap ketegangan suara), dan santa' (volume yang nyaring/keras). Ketiga konsep musikal itu senantiasa harus tercapai untuk mendukung terwujudnya kellèghân yang memadai. Teknik ajjhen pada dasarnya bertujuan "mendorong" suara yang keluar agar bertenaga. Tokang kèjhung senantiasa dituntut memiliki stamina suara yang prima untuk memperoleh vitalitas suara yang kuat dan konsisten.

Teknik yang mengkonsentrasikan diri pada tindakan "mendorong” suara ini kenyataannya menghasilkan dua karakter, yaitu suara lepas (sowara lowar) dan suara yang ditahan (sowara kènè). Hal ini sangat tergantung kebiasaan yang dimiliki masing-masing tokang kèjhung. Karakter sowara lowar kebanyakan disukai oleh tokang kèjhung lakè karena terasa lebih "lepas" (tidak ditahan di kerongkongan). Karakter semacam ini dianggap lebih merepresentasikan maskulinitas. Berbeda halnya dengan karakter sowara kènë yang lebih disukai oleh tokang kèjhung binè (meskipun tidak selalu demikian) karena terkesan lebih terasa feminin dan "tajam". Teknik ajjhen dengan sowara kènë menggunakan teknik makènè sowara, yaitu dengan cara menahan arus suara di tenggorokan (throat). Hal ini dilakukan agar kualitas suara yang keluar dari tokang kèjhung binè menjadi lebih "tajam" (memiliki clearity), terkesan ringan (bahkan cempreng). Melalui teknik menahan suara di tenggorokan, tokang kèjhung binë akan lebih mudah menjangkau nada-nada tinggi, lebih lincah dalam mengolah cengkok dan ornamen-ornamen kèjhungan dengan leluasa.

\section{Teknik pengaturan posisi rahang (belum} diketahui istilah lokalnya)

Teknik ini bertumpu pada pengaturan posisi rahang yang mengolah keluaran suara dengan cara menggerakkan rahang bagian bawah untuk mengatur besar bukaan mulut. Gerakan rahang dan perbedaan ukuran bukaan tersebut merupakan upaya tokang kèjhung untuk membantu pengaturan perpindahan dari nada satu ke nada lainnya, selain memunculkan efek suara tertentu. Sebagian pelaku kèjhungan, ada juga yang masih perlu menggerakkan kepalanya secara reflek (seperti sedikit mengguncang-guncangkan kepala) sebagai upaya memperlancar perpindahan dari nada satu ke nada lainnya. Teknik-teknik seperti itu relatif membantu mereka dalam mengeluarkan suara vokal yang diharapkan. 
Meskipun "permainan" gerakan rahang tersebut lebih diakui sebagai reflek tubuh dalam menjiwai kèjhungan daripada sebagai sebuah teknik, tetapi kenyataannya cara-cara itu dipelajari bersamaan dengan teknik ajjhen yang menggunakan teknik makènè sowara, yaitu dengan cara menahan arus suara di tenggorokan. Kelincahan mengolah nada-nada tinggi dalam kellèghãn akan terbantu dengan permainan (pengaturan) rahang tersebut. Cara paling praktis dari pengaturan posisi rahang ini adalah dengan sedikit memundurkan posisi kepala ke belakang atau rahang bawah didekatkan tenggorokan dengan posisi leher tetap tegak. Pengolahan suara dengan teknik ini lebih diminati oleh tokang kèjhung lakè karena hasil suara yang dihasilkan terkesan lebih tegas dan secara visual si pelakunya akan nampak lebih ekspresif karena gerakan otot-otot rahang dan guncangan kepalanya. Berbeda halnya dengan sikap tokang kèjhung binë yang lebih tenang dan selalu menutupi mulutnya dengan bentangan selendang atau saputangan ketika ia sedang ngèjhung (berdendang) di arena pentas.

Dalam rangka pencapaian kualitas suara yang diprasyaratkan, tokang kèjhung tidak hanya memberi perhatian pada hal teknis semata, tetapi juga menempuh praktik "perawatan suara" lewat upaya medis dengan cara aghurã (melakukan gurah) secara berkala, yaitu cara tradisional untuk mengeluarkan lendir dari dalam tubuh terutama kotoran di saluran pernapasan dengan meneteskan ramuan herbal ke mulut atau lubang hidung. Praktik "penjagaan suara" juga ditempuh melalui upaya mistik dengan cara praktik atau laku [Jw] spiritual.

Teknik-teknik vokal kèjhungan yang menekankan pada kekuatan, ketegangan suara, dan pencapaian kemantapan greget, tentu akan kering jika tidak didukung oleh penguasaan vokabuler dan daya interpretasi si pelakunya dalam membuat "isian" (ornamen) pada "draft" setiap frase kalimat lagu sebagai wadahnya. Oleh karena itu, interpretasi terhadap materi kalimat lagu dan lirik yang diambil dari parikan/pantun Madura itu akan melengkapi kesatuan bentuk kèjhungan secara utuh. Kèjhungan Yang-Layang, sebagai contohnya, sejatinya dari awal telah memberikan ruang tafsir yang luas bagi setiap tokang kèjhung untuk "menemukan" dan "menentukan" gaya kèjhungan-nya.

Praktik kèjhungan dapat pula memaparkan perbedaan implementasi teknik vokal yang lebih spesifik, yaitu interpretasi peran. Hal ini disebabkan adanya kesadaran peran untuk karakteristik läkè (maskulin) dan binè (feminin). Perbedaan itu nampak pada pola kellèghãn pada karakter lakè yang menunjukkan gejala melismatik yang relatif lebih tegas, menghentak (meletup-letup), dan kasar. Oleh sebab itu, greget yang menggebu (ghregghedhãn/ngaret) paling sering terjadi pada tokang kèjhung lakè yang lebih ekspresif (bebas dan berani). Sementara, pola kellèghãn karakter binë lebih dibatasi karena jika dilakukan seperti karakter laki-laki akan terkesan melampaui kepantasannya sebagai kèjhungan yang feminin. Kesadaran perannya sebagai "wanita" menyebabkan aspek greget tokang kèjhung binè tidak terlalu bertumpu pada teknik nyendhäl, melainkan pada teknik-teknik yang lainnya. Kèjhungan binë memiliki ruang yang dinamis untuk memberi banyak isian ornamen melodi di sepanjang pergerakan kontur melodinya.

\section{Pola Kellèghän dan Teknik Kèjhungan sebagai Representasi Ekspresi Budaya dan Pengalaman Estetik}

Apabila kita memperhatikan kembali karakteristik kèjhungan dan teknik vokalnya, maka petunjuk pentingnya terdapat pada gejala kontur melodi descending yang khas; pusat pengolahan nyanyian yang bertumpu pada nadanada tinggi dan diolah secara melismatis; tingkat ketegangan suara yang optimal; ekspresi vokal yang menggebu-gebu, menghentak, dan dibawakan secara emosional. Kèjhungan bärär (kèjhungan ala Madura Barat) ibarat seperti orang yang sedang berteriak, membentak, mengomel, bahkan di saat yang sama terkesan seperti merintih, mengeluh, meratap, dan sebagainya.

Melalui proses hermeneutik yang relatif lama dan berliku, penulis akhirnya menemukan adanya nilai-nilai penting dalam kèjhungan berupa dua konsep dasar yang sebetulnya berasal dari dua kosa kata yang sering diucapkan atau disandangkan ketika orang mendengar suatu kèjhungan. Dua 
kosa kata adalah ong-kalaongan (teriakan, sesuatu yang) dan lè-kalèllèan (meleleh, luluh, berkesan melas/sedih) yang nampaknya tidak disadari sebagai dasar estetik yang tertanam sebagai konsep dasar atas karakter kèjhungan itu sendiri. Kedua konsep tersebut nampak mewakili sifatsifat yang berlawanan, yaitu antara "kegarangan", "ketegangan" dan sifat-sifat "kepiluan", "kesedihan", sekaligus "keindahan". Kedua konsep inilah yang kemudian menghantarkan pada sebuah temuan pemahaman tentang konsep estetika kèjhungan yang komprehensif.

Ong-kalaongan secara harafiah adalah teriakan dari kejauhan, suara yang lantang-melengking, sepadan dengan istilah rag-oraghãn, tha'-karatha'an. Ong-kalaongan berkaitan dengan kualitas ketegangan suara tokang kèjhung yang dituntut untuk mampu melontarkan suaranya hingga terdengar dari jarak yang jauh. Sementara, lè-kalèllèan berasal dari kata alèllè, artinya meleleh atau luluh. Istilah lèkalèllèan secara harafiah adalah sesuatu yang meleleh, berderai, bertetesan, dan meluruh. Masyarakat tineliti sering mengucapkan kedua istilah tersebut manakala ingin mengungkapkan kesan tentang kèjhungan yang bercirikan permainan nada-nada tinggi yang didominasi oleh motif-motif melodi nyanyian melismatis yang dikatakan "indah" (perna [Mdr]). Kesan tersebut merupakan sebuah indikasi yang mengarah pada pemahaman genetika lokal gaya nyanyian yang khas, berkonotasi sebagai kelantangan lantunan nyanyian yang "indah" (perna) atau "manis" (manès). Bagi penulis, konsep estetik tersebut sangat penting keberadaannya, sebab hal itu akan menjadi penghubung dengan dunia ide atau dunia pengalaman (referensial) yang sangat luas.

Barangkali yang perlu ditelusuri adalah gagasan-gagasan utamanya atau ide dasar yang melandasi lahirnya konsep estetik tersebut. Lantas dari mana datangnya sumber gagasan atau ide dasar tersebut? Secara teoritis, kita sering mendengar bahwa keberadaan suatu gaya nyanyian merupakan cerminan karakteristik orangnya atau budayanya. Demikian pula tentang perilaku budaya seseorang atau masyarakat sangat dibentuk oleh lingkungan dan budaya tradisinya itu sendiri, yaitu alam, perwatakan manusianya, sistem sosial yang dijalankan, sejarah yang telah dilaluinya, dan keyakinan masyarakatnya.

Penulis merefleksikan relasi antara kèjhungan (bentuk, prilaku [teknik], konsep, dan maknanya) dengan konteks budaya yang lebih luas. Dimensi yang paling penting untuk dilihat adalah faktorfaktor karakteristik manusianya atau perwatakan dan sifat khas perilaku sebagai agen yang menentukan "standart" selera estetikanya. Tentu saja karakteristik seseorang sangat dipengaruhi oleh faktor lainnya (dalam ranah yang lebih luas) yaitu sesuatu yang turut menyebabkan mengapa orang Madura tumbuh dengan karakteristik seperti itu. Ranah ini sangat luas isinya karena ditopang oleh berbagai faktor, diantaranya adalah faktor sejarah sosial, faktor ideologis (keyakinan/mitos), faktor tipologi geografis (geo-budaya/politik/ekonomi), dan sebagainya. Faktor-faktor tersebut baik secara langsung maupun tidak langsung turut memberi andil terhadap suasana mental masyarakat Madura (Lihat De Jonge, 1989a, 1990, 2012).

Banyak tulisan yang telah berusaha menjelaskan karakteristik masyarakat Madura dari berbagai sudut pandang, seperti penggalian karakteristik melalui citra peribahasanya (Mien Rifai, 2007), melalui perspektif kajian antropologiekonomi (Huub De Jonge, 1989b), kajian sejarah sosial (Kuntowijoyo, 1993 dan 2002), kajian sosial-politik (Abdur Rozaki, 2004), serta topiktopik mengenai fenomena citra kekerasan yang banyak ditulis oleh sarjana luar negeri maupun dalam negeri, seperti Elly Touwen-Bouwsma, Kees van Dijk, Petebang-Sutrisno, Latief Wiyata, dan sebagainya. Penggambaran karakteristik budaya Madura melalui kajian-kajian ilmu sosial tersebut hampir selalu dibayangi oleh berbagai stereotip yang berkembang hingga kini. Stereotip merupakan penilaian generalistik yang selalu diliputi prasangka (negatif), diperbandingkan, dan menonjolkan sisi-sisi buruk, tetapi di satu sisi stereotip masih mempunyai makna yang menuntun pikiran dan tindak-tanduk manusianya.

Dalam ikhtisar singkat ini, penulis tidak akan mengupas secara menyeluruh mengenai karakteristik orang Madura yang sedemikian banyak itu, baik yang diangkat dari kancah stereotip maupun dari orang Madura di dalam memandang 
dirinya sendiri. Penulis akan memilih beberapa karakter yang memiliki hubungan dengan topik tulisan ini. Karakter yang relevan dan umum adalah karakter orang Madura yang tempramental, gaya bicaranya kasar dengan logat yang kental, nada bicaranya tinggi, lantang, dan meletup-letup (tha'karatha'an) terutama bila bergairah. Karakter atau sifat temperamental seringkali dinyatakan dalam bentuk karakter yang emosional, beringas (ghãthag), menggebu-gebu, tidak terkendali. Ada pula karakter orang Madura yang memiliki sifat-sifat percaya diri, berani, terbuka (blak-blakan), tandas, energik, ghendhãg (pamer), serta bebas. Karakter kebebasan itu seringkali dianggap/dinyatakan sebagai bentuk kekasaran, keterburu-buruan, tidak memiliki rasa sungkan, ataupun dianggap kurang sopan. Karakter lainnya yang masih relevan adalah karakter gherra (kaku), koko (kokoh), dan saduhuna (apa adanya).

Beberapa karakteristik orang Madura tidak terlepas dari makna baik atau buruk yang nampaknya sangat berkaitan atau memiliki kesamaan makna dengan karakteristik suara kèjhungan yang dianggap ideal. Ketegangan suara yang lantang dan tinggi, gerakan kontur melodi kellèghän yang ekstrim, pengolahan ekspresi ghregghedhän/ngaret yang ditonjolkan, dan teknik vokal yang menekankan pada kekuatan tenaga, merupakan refleksi dari totalitas ekspresi yang dinyatakan oleh orang Madura lewat gaya nyanyiannya. Pada titik ini, kèjhungan dapat menjadi petunjuk situs sejarah atas ekspresi-ekspresi budaya mereka.

Sifat-sifat orang Madura di atas apabila dirangkum dalam satu kosa kata yang dipandang representatif, maka sebagaimana dikatakan De Jonge $(1995,2012)$, kata yang dinilai signifikan adalah "kekerasan", tentu saja dalam pengertian yang luas. Kekerasan di Madura seringkali lebih dilihat dari sisi perilaku masyarakatnya sebagai supremasi penilaian orang luar terhadap karakteristik orang Madura secara umum. Dalam bentuknya yang lain, nilai kekerasan dapat ditemukan pula dalam tradisi budaya Madura, contohnya melalui tradisi arisan "rèmoh", ojhung (ritual perkelahian meminta hujan), karapan sapi, aduan sapi, aduan burung, aduan layang-layang, dan berbagai aduan lainnya. Kekerasan sebetulnya juga harus dilihat tidak sebatas dalam artian secara fisik, melainkan harus sampai pada sisi kekukuhannya dalam mempertahankan prinsip dan keyakinannya terhadap sesuatu yang dianggap baik, benar, dan nyaman bagi dirinya. Tidak mengherankan jika pada akhirnya kekerasan itu seakan dilakukan dan dihadapinya dengan penuh percaya diri.

Kuntowijoyo (2002) menyarankan bahwa untuk melihat akar "kekerasan" orang Madura harus dilihat melalui narasi sejarah sosialnya. Setidaknya hal ini dapat membuka pemahaman dasar mengapa karakteristik orang Madura menjadi demikian khas. Kekerasan orang Madura sangat berkaitan dengan 1) perekonomian masyarakat Madura yang hidup di lahan pertanian yang tidak subur dan amat bergantung pada hujan yang curahnya rendah, menyebabkan kemiskinan. 2) Pengaruh ekologi fisik menyebabkan tatanan kepemukiman masyarakatnya terpencar-pencar dalam kelompok kecil-kecil, sehingga sulit membentuk solidaritas desa dan lebih tersosialisasi untuk memiliki rasa percaya diri yang individual dan protektif. Dari sisi politik, Rifai (2007: 36-37) menilai bahwa 3) pada masa swapraja penuh, penguasanya dari pribumi, di Madura sepanjang abad XVIII hingga pertengahan abad XIX merupakan puncak masa kemiskinan yang amat panjang menyengsarakan rakyat dan menyuburkan berbagai kekerasan di tengah masyarakat Madura. 4) Kepadatan penduduk yang tinggi di pulau Madura disertai kesulitan ekonomi yang berkepanjangan sejak abad ke 19 membuat rakyat Madura harus hidup dalam persaingan yang tinggi, bahkan harus bermigrasi besar-besaran ke pulau lain. Rozaki (2004) juga menyimpulkan bahwa 5) masyarakat Madura di masa kapitalisme kolonial itu mengalami proses eksploitasi dan dehumanisasi.

Temuan Sudagung (2001: 131) atas pendalamannya pada teori-teori perilaku, menyimpulkan bahwa pembawaan dan perilaku orang Madura terbentuk karena terpaan lingkungan alam yang gersang dan tandus, sumber daya alam hayati yang tidak mencukupi memenuhi kebutuhan, serta lingkungan sosial yang penuh dengan tantangan persaingan. Intinya bahwa kondisi sumber daya yang serba terbatas, menyebabkan tumbuhnya karakter sensitif di kalangan masyarakat Madura. 
Berdasarkan pengalaman historis yang sedemikian rupa, ekspresi-ekspresi budaya melalui karya-karya seni tradisi Madura senantiasa menjadi situs reflektif atas keberadaan masyarakatnya. Jika keberadaan suatu nyanyian merupakan representasi dari ekspresi jiwa masyarakatnya, maka kèjhungan dengan segala karakteristik dan kesadaran pelakunya memperlihatkan hubungan fakta-fakta musikal, konsep estetik, dan ide dasarnya. Paparan sejarah sosial, perwatakan, dan perilaku orang Madura yang dikemukakan oleh banyak peneliti telah menjadi episode latar belakang dari budaya kèjhungan. Ranah itu telah menggiring pada pemahaman nilainilai yang penting dalam karakteristik kèjhungan dan ide-ide yang membentuknya, seperti tentang pergolakan, gejolak, agresifitas, kekuatan, amarah, kekerasan, sekaligus tentang romantika kehidupan orang Madura di masa silam yang penuh kegetiran. Pengalaman historis dan perwatakan orang Madura yang mengisahkan adanya pergolakan batin itu nampaknya mengilhami sosok ekspresi atau gaya nyanyian sesuai dengan cara-cara ungkap yang sangat mempribadi dengan karakteristik manusianya.

Hubungan karya estetik kèjhungan dengan budaya masyarakat Madura seharusnya dapat dibaca secara kronologis. Munculnya pemahaman ong-kalaongan dan lè-kalèllèan sebagai konsep dasar estetika kèjhungan juga menjadi bukti atas ideide dasar yang mempribadi dalam benak orang Madura tersebut. Konsep estetik ini merupakan tesis atas gagasan tentang nilai-nilai pengalaman sejarah sosial masyarakat Madura. Ong-kalaongan dan lè-kalèllèan, memperlihatkan dualisme karakter kèjhungan yang bersifat "garang" (kekerasan) dan "sedih" (kepiluan, kegemulaian). Bertolak dari konsep estetik inilah kemudian wujud ekspresi nyanyian dibangun dan dilahirkan sehingga kèjhungan bukan sekadar wujud nyanyian yang unik, melainkan memaparkan cara-cara orang Madura mengekspresikan jiwanya.

Fakta musikal berupa ekspresi-ekspresi suara yang menegang disajikan dalam kualitas suara yang lantang, nada yang tinggi, menggebu. Hal itu menyatu dengan ekspresi merintih yang disajikan melalui motif-motif melodi melismatis. Kellèghãn merupakan pertemuan yang mengakomodasi ekspresi ketegangan dan rintihan, atau sebagai penjabaran atas konsep estetik kèjhungan ongkalaongan dan lè-kalèllèan. Pola-pola kellèghãn yang menjadi inti kèjhungan itu telah menjadi bagian dari pengalaman estetik yang demikian terbaca sebagai nyanyian "jiwa” orang Madura. Rassa mellas (rasa sedih) dan karakteristik garang-menghentaklantang bukanlah sebuah kontradiksi, melainkan menjadi satu keutuhan antara suasana batin kegetiran dan amarah. Dua dimensi suasana batin tersebut pada akhirnya menjadi muara bagi estetika kèjhungan Madura itu sendiri. Di sinilah, penulis menemukan pemahaman tentang inti pengalaman estetik orang Madura, yaitu kekerasan dan kepiluan. Menurut Blacking (1974: 5), musik tumbuh dari perasaan dan pengalaman masyarakatnya. Tidak heran jika ia kemudian menempatkan suara/musik sebagai subjek atau entitas yang dapat menjelaskan suatu kebudayaan masyarakat tertentu. Musik itu mewakili keberadaan manusianya.

Kèjhungan secara mendalam telah merepresentasikan nilai "kejiwaan" dan sekaligus "eksistensi" tentang diri orang Madura (sifat-sifat kemaduraan). Pada akhirnya, kèjhungan tidak selayaknya jika hanya dikesankan atau dimaknai sebatas seperti orang yang sedang berteriak-teriak, memberontak, berkeluh-kesah, ataupun meratap. Sebab, kronologinya itu demikian jelas terpampang dari hubungan tekstual kèjhungan dengan konteks budayanya. Bagaimanapun bentuk nyanyiannya merupakan pengejawantahan atas ekspresi jiwa budayanya (culture spirit) yang tidak terbantahkan, secara terus-menerus digunakan dan dimaknai dalam kerangka tradisi.

Ekspresi seni yang eksis, dalam pandangan Bruner dan Turner (1986: 5-11), sesungguhnya merupakan pencerminan atas pengulangan dari suatu pengalaman, baik dengan cara pengulangan seperti re-live, re-create, re-tell, re-construct, dan re-fashion terhadap kebudayaannya. Ekspresi dan pengalaman memiliki hubungan dialektis, yaitu ketika "pengalaman menstruktur ekspresi", maka "ekspresi juga dapat menstruktur pengalaman". Melalui kedua hubungan pengalaman dan ekspresi itu, sesungguhnya pemaknaan indigenous dapat ditemukan, sebab ekspresi tersebut merupakan artikulasi, formulasi, dan representasi dari pengalaman mereka sendiri (Gambar 3). 
Representasi : ekspresi budaya dan pengalaman estetik

(Nilai-Nilai Kemaduraan)

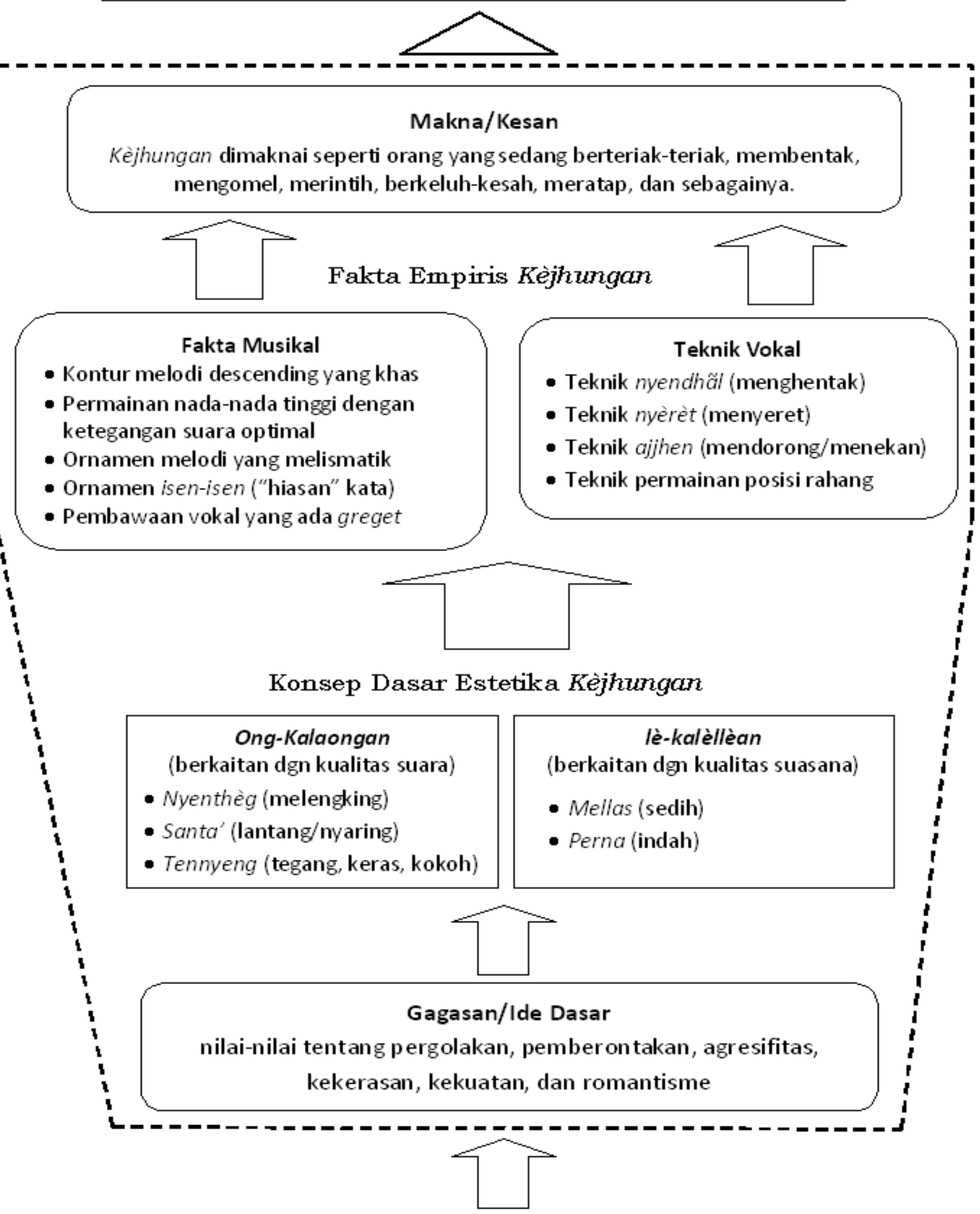

\section{Latar Belakang Budaya}

Faktor perwatakan dan perilaku manusianya; faktor sejarah sosial; faktor ideologis (keyakinan/mitos), faktor tipologi geografis (geo-budaya/politik/ekonomi) 


\section{Penutup}

Aspek-aspek penting dari kèjhungan adalah tentang pemolaan nada-nada tinggi (kellèghãn), ketegangan suara, kemantapan greget, yang kesemuanya itu terbingkai dalam pemahaman estetik ong-kalaongan dan lè-kalèllèan sebagai intinya. Tidak ada yang paling penting dari ketiga aspek tersebut, sebab ketiganya menjadi satu kesatuan utuh di dalam kèjhungan. Hanya saja, kellèghãn paling sering dibicarakan karena wujudnya berupa materi pola cengkok yang menyita perhatian pelaku kèjhungan. Sesungguhnya, kellèghãn itu sendiri dibentuk oleh ketegangan suara dan kemantapan greget. Sebegitu menonjolnya kebutuhan terhadap ketegangan suara dan kemantapan greget, mengakibatkan aspek ketepatan nada ( $p$ itch) secara praksis kadang tidak lagi menjadi hal yang diutamakan. Kellèghãn merupakan kontur utama dari bentuk kèjhungan, selalu muncul di bagian awal frase nyanyian dengan gerakan yang khas memadukan antara level nada tinggi, motif melismatis, dan teknik-teknik vokal yang khas pula (nyendhãl, nyèrèt, ajjhen, memainkan bukaan rahang mulut).

Kellèghãn dianggap paling sulit, memeras tenaga, dan menuntut rasa percaya diri dari pelakunya, namun harus dikuasai, sehingga pencapaian nada tinggi melengking dan tenaga suara yang powerfull menjadi tuntutan paling ideal. Kellèghãn ibarat wajah dari kèjhungan seseorang yang kadang siap mempermalukan pembawanya jika dilakukan setengah hati. Kemampuan mereka me-ngèjhung seakan ditentukan oleh cara mereka membawakan pola kellèghãn dengan segenap penghayatan memadukan dualisme karakter "garang" dan "pilu". Kellèghân seakan menjadi inti dari paparan ekspresi "keluh-kesah"-nya orang Madura lewat nyanyian yang setidaknya mencerminkan spirit masa silam Madura yang penuh kegetiran dan perjuangan.

Kèjhungan telah membuktikan sebagai ekspresi gaya nyanyian yang dapat menerangkan pengalaman terdalam manusia, dan juga dapat menghantarkan imajinasi atau persepsi masyarakat pemiliknya ke arah pengalaman tertentu. Bentukbentuk hubungan kèjhungan dengan ekspresi budaya "masa silam" tersebut senantiasa diwariskan hingga sekarang melalui praktik-praktik pertunjukan pada konteksnya yang beragam, ataupun praktik-praktik kèjhungan dalam berbagai kesempatan. Pewarisan yang terus-menerus ini tentu dalam konteks pengulangan yang kualitasnya bermakna statis ataupun dinamis.

\section{Kepustakaan}

Blacking, John. 1974. How Musical is Man? Seattle: University of Washington Press.

Bouvier, Helene. 2002. Lebur! Seni Musik dan Pertunjukan dalam Masyarakat Madura. Terj. Rahayu S. Hidayat dan Jean Couteau. Jakarta: Yayasan Obor.

Bruner, Edward M. dan Victor W. Turner. 1986. The Anthropology of Experience. Chicago: University of Illinois Press.

Clippinger, David A. 2006. The Head voice and Other Problems: Practical Talks on Singing. The Project Gutenberg eBook.

Dijk, Kees van., Huub de Jonge and Elly TouwenBouwsma (Eds.). 1995. Across Madura Strait: The Dynamics of An Insular Society. Leiden: KITLV Press.

Endraswara, Suwardi. 2005. Tradisi Lisan Jawa. Yogyakarta: Narasi.

Jonge, Huub De. ed. 1989a. Agama, Kebudayaan, dan Ekonomi. Terj. Suparmin. Jakarta: Rajawali Press.

.1989b. Madura dalam Empat Zaman: Pedagang, Perkembangan Ekonomi, dan Islam. Seri terjemahan KITLV-LIPI. Jakarta: PT Gramedia.

2012. Garam, Kekerasan, dan Aduan Sapi: Esai-Esai tentang Orang Madura dan Kebudayaan Madura. Terj. Arief B. Prasetyo. Yogyakarta: LKiS.

Kuntowijoyo. 1993. Radikalisasi Petani: Esei-Esei Sejarah. Yogyakarta: Bentang Intervisi Utama. 2002. Perubahan Sosial dalam 
Madura 1850-1940. Yogyakarta: Mata Bangsa, bekerja sama dengan Yayasan Adikarya IKAPI dan The Ford Foundation.

Lomax, Alan. 1976. Cantometrics: An Approach to The Anthropology of Music. Audiocassettes and A Handbook. California: The University of California.

Mistortoif, Zuelkarnain, dkk. 2010. "Kejhungan: Gaya Nyanyian Madura dalam Pemaknaan Masyarakat Madura Barat pada Penyelenggaraan Tradisi Remoh" dalam Resital Jurnal Seni Pertunjukan, Volume 11. No. 1, Juni.

Pawitra, Adrian. 2003. Kumpulan Lagu-Lagu Madura. Jakarta: Lembaga Pelestarian Kebudayaan Madura.

Petebang, E. dan Sutrisno, E. 2000. Konflik Etnis di Sambas. Jakarta: ISAI.

Rifai, Mien Ahmad. 2007. Manusia Madura: Pembawaan, Prilaku, Etos Kerja, Penampilan, dan Pandangan Hidupnya seperti Dicitrakan Peribahasanya. Yogyakarta: Pilar Media.

Rozaki, Abdur. 2004. Menabur Kharisma Menuai Kuasa, Kiprah Kiai dan Blater sebagai Rezim Kembar di Madura. Yogyakarta: Pustaka Marwa.

Silverberg, Misoon Ghim. 2010. "'He Was Despised' In Writing And Performance: A Study Of Vocal Ornamentation In One Aria From Handel's Messiah Using Objective And Subjective Listening Practice", [Dissertation]. Temple University Graduate Board.

Sumarsam. 2003. Gamelan: Interaksi Budaya dan Perkembangan Musikal di Jawa. Yogyakarta: Pustaka Pelajar.

Supriyanto, Henricus. 2004. "Kidungan Ludruk". Surabaya: Pemerintah Provinsi Jawa Timur bekerja sama dengan Widya Wacana Nusantara (WICARA).

Wiyata, Latief. 2002. Carok: Konflik Kekerasan dan Harga Diri Orang Madura. Yogyakarta: LKIS.

Zanten, Wim van. 1989. Sundanese Music in The Cianjuran Style, Anthropological and Musicological Aspect of Tembang Sunda. U.S.A: Foris Publications.

\section{Informan}

Abdurrachman, R (62 th). Seniman tari dan karawitan Madura yang berasal dari kalangan bangsawan; mantan birokrat kesenian Dati II Kab. Bangkalan; Ia tinggal di Desa Kemuning, Kecamatan Burneh.

Adrian Pawitra (42 th). Budayawan, pencipta lagu pop daerah Madura, dan penulis Kamus Bahasa Madura; dari Desa Pangeranan, Kecamatan Kota (Bangkalan).

Dãi (56 th). Penabuh senior, mempunyai kemampuan memainkan semua alat musik gamelan sandur terutama bonang dan kendang; Ia berasal dari Desa Keleyan, Kecamatan Socah.

Ghaib (75 th [?]). Tokoh blatèr; pernah berperan sebagai tokang panggil arisan rèmoh di beberapa wilayah di Madura dan Surabaya pada dekade 70-80an; Ia tinggal di Desa Banjar, Kecamatan Galis.

Mohammad (57 th). Sesepuh blatèr sekaligus Klèbun atau Kepala Desa, hingga kini masih aktif sebagai seorang blatèr. Ia berasal dari Desa Jeddih, Kecamatan Socah.

Mudrick (62th). Tokang panjhäk (pengendang, tokang kejhung lakè, panjhäk lako [pemeran tokoh dagelan]). Ia adalah tokoh senior di kalangan pekerja seni sandur Madura dan dihormati oleh kalangan blatèr hingga akhir hayatnya; Ia berasal dari Desa Pangeranan, Kecamatan Kota (Bangkalan).

Sadun (45 th). Tokang kèjhung binë (karakter feminin/perempuan); Ia tinggal di Perumnas Kecamatan Kamal.

Sumbri (52 th). Tokoh blatèr yang sekarang menempati posisi sebagai ketua rombongan rèmoh di wilayahnya; Ia tinggal di Desa Petrah, Kecamatan Tanah Merah.

Turi, H (61 th). Mantan tokang kèjhung terkenal di masa 1970-1980an; sesepuh kelompok sandur di wilayah Sampang, dan sangat dihormati kalangan blatèr hingga akhir hayatnya; Ia berasal dari Kecamatan Pandamawu, Kabupaten Pamekasan. 